\title{
DETERMINAN YANG BERHUBUNGAN DENGAN KEBERADAAN JENTIK DI KELURAHAN RANGKAH BUNTU, SURABAYA
}

\section{DETERMINANT FACTOR OF LARVA EXISTENCE ON THE RANGKAH, SURABAYA}

\author{
Alivia Sasa Muda1), Dani Nasirul Haqi2) \\ 1Departemen Promosi Kesehatan dan Ilmu Perilaku, Fakultas Kesehatan Masyarakat, Universitas \\ Airlangga Surabaya \\ 2Departemen Kesehatan dan Keselamatan Kerja, Fakultas Kesehatan Masyarakat, Universitas \\ Airlangga Surabaya \\ E-mail: alivia.sasa.muda-2016@fkm.unair.ac.id
}

\begin{abstract}
Background: Dengue Hemorrhagic Fever is still a problem in Indonesia. In 2016, the number of deaths in East Java due to dengue as much as 339 people or 1.4\% of total patients. At the end of 2017, 4 cases of dengue fever were found in the RW. VI, Rangkah Buntu Village, Surabaya. One of the causes of dengue is the presence of larvae. Purpose: The purpose of this study to analyze the factors that affecting the presence of larvae in Rangkah Buntu Village. Methods: This research is an observational analytic research with quantitative approach. The study included cross sectional with a sample of 211 respondents. The sampling technique used is simple random sampling. The independent variables in this study were education, income, knowledge, attitude, $3 \mathrm{M}^{+}$, hanging dirty clothes for more than one day, draining the bath at least once a week and cleaning the house. And the dependent variable is the presence of larvae. Data collection techniques are divided into primary data (direct observation and questionnaire) and secondary data (journals and articles). Then the data were analyzed by chi square test with the help of SPSS program to see the influencing factor. Results: The results of this study indicate that the knowledge, activity of draining the bath tub at least once a week and hanging dirty clothes more than one day have an influence with the presence of larvae (chi square obtained $p<a(a=0.05)$ ). Conclusion: There is no significant relationship between education, income, attitude, $3 \mathrm{M}^{+}$, and cleaning the house with the presence of larva in RW.VI area, Rangkah Buntu Village, Surabaya.
\end{abstract}

Keywords: presence of larvae, influencing factors, dengue fever

\begin{abstract}
ABSTRAK
Latar Belakang: Demam Berdarah Dengue masih menjadi masalah di Indonesia. Tahun 2016, jumlah kematian di Jawa Timur akibat DBD sebanyak 339 orang, atau persentasenya 1,4\% dari total penderita Pada akhir tahun 2017, ditemukan 4 kasus demam berdarah di wilayah RW. VI Kelurahan Rangkah Buntu Kota Surabaya. Salah satu indikator penyebab DBD adalah keberadaan jentik. Tujuan: tujuan penelitian ini untuk menganalisis faktor yang memengaruhi keberadaan jentik di Kelurahan Rangkah Buntu. Metode: Penelitian ini merupakan penelitian observasional analitik dengan pendekatan kuantitatif. Penelitian ini termasuk cross sectional dengan sampel 211 responden. Teknik yang digunakan dalam pengambilan sampling adalah simple random sampling. Variabel independen penelitian adalah pendidikan, pendapatan, pengetahuan, sikap, $3 \mathrm{M}^{+}$, menggantung pakaian kotor lebih dari satu hari, menguras bak mandi minimal satu minggu sekali, dan membersihkan rumah. Variabel dependen adalah keberadaan jentik. Teknik pengumpulan data dibedakan menjadi data primer (pengamatan langsung dan kuesioner) dan data sekunder (jurnal dan artikel). Kemudian data dianalisis dengan uji chi square dengan bantuan program SPSS untuk melihat faktor yang berpengaruh. Hasil: Hasil penelitian ini menunjukkan bahwa pengetahuan, aktivitas menguras bak kamar mandi minimal satu minggu sekali dan menggantung pakaian kotor lebih dari satu hari memiliki pengaruh dengan keberadaan jentik (chi square didapatkan hasil $p<a(a=0,05)$ ).
\end{abstract}


Kesimpulan: Tidak ada hubungan yang signifikan antara pendidikan, pendapatan, sikap, 3M+, dan membersihkan rumah dengan keberadaan jentik di wilayah RW.VI Kelurahan Rangkah Buntu, Kota Surabaya.

Kata Kunci: keberadaan jentik, faktor yang memengaruhi, demam berdarah

\section{PENDAHULUAN}

Asia berada pada urutan pertama dalam jumlah penderita DBD setiap tahunnya yang didapat dari data seluruh dunia. Daerah tropis dan sub tropis, dominan ditemukan Demam Berdarah Dengue. WHO (2009) sejak tahun 1968 hingga tahun 2009 mencatat kasus DBD tertinggi di Asia Tenggara ada di Indonesia (Buletin Jendela Epidemiologi, 2010).

Tahun 1970, hanya terdapat 9 negara yang mengalami wabah DBD, namun sekarang DBD menjadi penyakit endemik pada lebih dari 100 negara, diantaranya Afrika, Negara Paman Sam (Amerika), Mediterania Timur, Asia Tenggara dan Pasifik Barat. Jumlah kasus di Amerika Tenggara dan Pasifik Barat telah melewati 1,2 juta kasus di tahun 2008 dan lebih dari 2,3 juta kasus di 2010. Pada tahun 2013 dilaporkan 37.687 kasus DBD berat dari jumlah total sebanyak 2,35 juta kasus di Amerika (Kemenkes, 2016).

Kementerian Kesehatan (2010) menyatakan bahwa Demam Berdarah Dengue masih menjadi masalah utama di Indonesia. Tahun 2015, tercatat dari 34 Provinsi di Indonesia terdapat sebanyak 126.675 penderita DBD dan 1.229 orang diantaranya meninggal dunia. Jumlah tersebut lebih tinggi dibanding tahun sebelumnya, yakni sebanyak 100.347 penderita DBD dan sebanyak 907 penderita meninggal dunia tahun 2014. Bahaman menghadapi titik balik terkait dengan relevansi DB sebagai krisis kesehatan masyarakat yang berpotensi merugikan bagi kelangsungan hidup dan ekonomi negara. Sudah saatnya untuk sektor kesehatan masyarakat mengambil langkah untuk mengembangkan kebijakan pemberantasan DB komprehensif. Meskipun pengurangan populasi vektor aedes dengan menggunakan insektisida tampak menjanjikan, namun itu merupakan tujuan yang sulit dicapai (Sherrie V. Bain. 2011). Penggunaan insektisida dalam memberi kontrol terhadap perkembangan vektor nyamuk menimbulkan kekhawatiran tentang dampak lingkungan (WHO, 2009)

Tahun 2016, total jumlah penderita DBD di Jawa Timur 24.098 orang, dengan rata-rata 61,9/100.000 penduduk (peringkat ke-16 di Indonesia). Jumlah kematian akibat DBD sebanyak 339 orang, atau persentasenya 1,4\% dari total penderita (Grahadi, 2017). Tahun 2017, ditemukan 4 kasus demam berdarah di Kelurahan Rangkah Buntu Kota Surabaya.

Famili Culicidae merupakan golongan Aedes aegypti, yang berperan sebagai vektor Demam Berdarah Dengue. Ae. aegypti dan Ae. albopictus adalah nyamuk yang berperan sebagai vektor potensial utama DBD di Indonesia. Penularan DBD terjadi melalui gigitan nyamuk $A e$. aegypti atau Ae. albopictus betina yang sebelumnya telah membawa virus dalam tubuhnya dari penderita demam berdarah lain (Ishartadiati, 2012). Ae. aegypti mengalami metamorfosis lengkap atau metamorfosis sempurna (holometabola) yang melalui beberapa tahap yaitu Telur, Larva, Pupa, dan Dewasa.

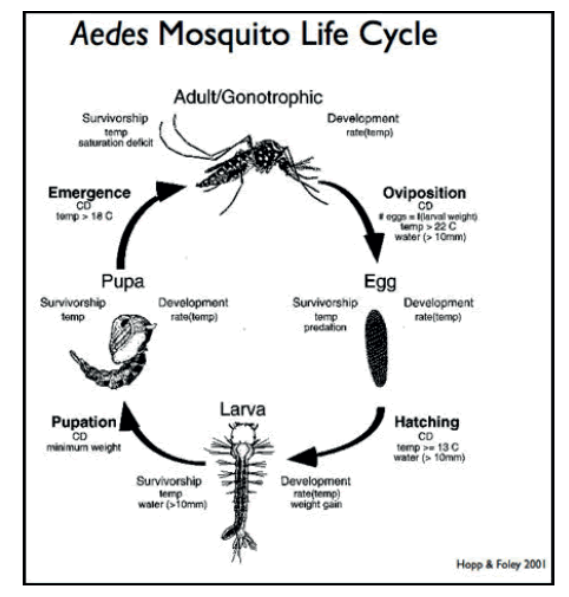

Sumber: Yimer Muktar, 2017

Gambar 1. Siklus daur hidup nyamuk Aedes aegypti

Telur akan menetas jika kelembaban terlalu rendah dalam waktu 4 atau 5 hari. 
Larva akan berkembang menjadi pupa dalam waktu 5-7 hari. Larva lebih menyukai air bersih, akan tetapi tetap dapat hidup dalam air yang keruh baik bersifat asam atau basa. Pupa membutuhkan waktu 1-3 hari sampai beberapa minggu untuk menjadi nyamuk dewasa. Nyamuk Aedes aegypti betina hanya kawin satu untuk meneruskan keturunan. Biasanya perkawinan terjadi 24-28 hari saat nyamuk dewasa.

Keberadaan jentik merupakan indikator adanya demam berdarah sehingga pemberantasan jentik terus diupayakan guna meminalisir keberadaan jentik dan memutus mata rantai perkembangan vektor Aedes. Pengendalian vektor melalui surveilans vektor diatur dalam Kepmenkes No. 581 tahun 1992, bahwa kegiatan Pemberantasan Sarang Nyamuk (PSN) dilakukan secara periodik oleh masyarakat yang dikoordinir oleh RT/RW dalam bentuk PSN dengan pesan inti $3 \mathrm{M}$ plus. ABJ merupakan singkatan dari Angka Bebas Jentik, ini digunakan dalam mengukur keberhasilan PSN $\geq 95 \%$ adalah nilai yang diharapkan untuk $A B J$, dengan demikian penularan DBD dapat dicegah.

Sumber: HL. Blum, 1974

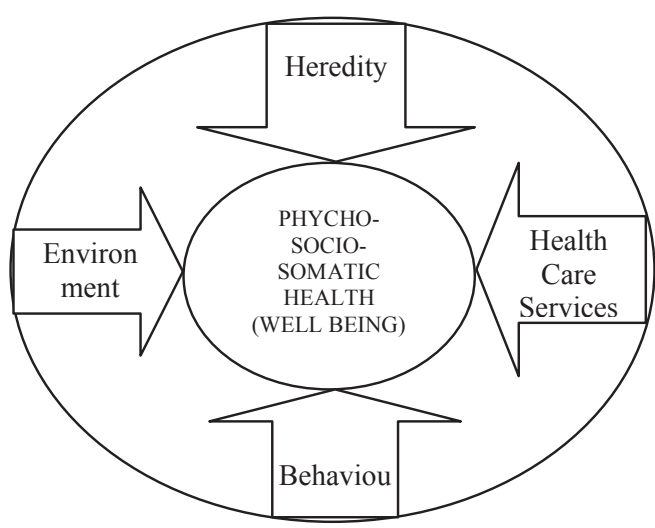

Sumber: HL. Blum, 1974

\section{Gambar 2. Bagan Faktor yang memengaruhi Derajat Kesehatan}

Pencegahan DBD dapat dilakukan dengan perilaku PSN. PSN merupakan salah satu upaya perilaku kesehatan yang dapat menurunkan keberadaan jentik. Beberapa faktor yang dapat memengaruhi derajat kesehatan (HL. Blum, 1974; Notoadmodjo, 2010) adalah pelayanan kesehatan, genetik, perilaku, dan lingkungan. Selain perilaku PSN, faktor lain yang berpengaruh terhadap derajat kesehatan adalah lingkungan. Peran lingkungan terhadap penyakit DBD (Hendra Kurniawan, 2011) terdiri dari:

1. Kepadatan Penduduk

Semakin padat penduduk, semakin mudah nyamuk Aedes menularkan virusnya dari satu orang ke orang lainnya sehingga salah satu faktor risiko penularan penyakit DBD adalah kepadatan penduduk. Pola tertentu yang tidak dimiliki pertumbuhan penduduk dan urbanisasi yang tidak terencana serta tidak terkontrol merupakan salah satu faktor yang berperan dalam munculnya kembali kejadian luar biasa penyakit DBD

2. Mobilitas Penduduk

Mobilitas penduduk telah menjadi penyebab dan penerima dampak dari perubahan dalam struktur ekonomi dan sosial di suatu daerah, tanpa terlepas dari penyebaran penyakit tertentu.

3. Sanitasi Lingkungan

Perkembangbiakan nyamuk Aedes dipengaruhi terutama oleh kondisi sanitasi lingkungan, misalnya terdapat banyak kontainer penampungan air hujan yang berserakan dan terlindung dari sinar matahari, apalagi berdekatan dengan rumah penduduk.

4. Keberadaan Kontainer

Tingginya risiko terinfeksi virus DBD bisa disebabkan oleh semakin banyaknya kontainer karena hal tersebut akan memicu semakin banyak tempat perindukan nyamuk sehingga populasi Aedes makin padat dan waktu penyebaran lebih cepat. (Ditjen PPM\&PL, 2001) berupa penyuluhan kesehatan masyarakat dalam penanggulangan penyakit DBD antara lain dengan cara Menguras, Menutup, dan Mengubur (3M) sangat tepat dan perlu dukungan luas dari masyarakat dalam pelaksanaannya.

5. Kepadatan Vektor

Semakin tinggi angka kepadatan vektor akan meningkatkan risiko penularan penyakit DBD.

Beberapa faktor yang berhubungan dengan penyakit DBD yaitu perilaku dalam pengendalian vektor yang dapat 
dilakukan secara kimiawi, biologi maupun dengan manajemen lingkungan. Pengendalian vektor secara kimiawi menggunakan insektisida. Sasaran insektisida berupa stadium dewasa ataupun stadium pradewasa. Insektisida merupakan racun bersifat toksik. Pelaksanaannya jenis insektisida, dosis dan metode menjadi hal penting untuk dipahami dalam kebijakan pengendalian vektor. Secara Biologi Penggunaan vektor dilakukan dengan menggunakan predator, pemangsa, parasit, dan bakteri yang merupakan agen biologi. Jenis predator yang digunakan yaitu ikan pemakan larva seperti ikan guppy, cupang, tampalo, dan ikan gabus.

Secara manajemen lingkungan upaya mengurangi vektor DBD dilakukan dengan pengelolaan lingkungan, sehingga perkembangbiakan nyamuk menjadi tidak kondusif. Penanggulangan ini bisa diaplikasikan dengan cara menguras, menutup, dan mengubur serta melakukan hal lain yang menunjang pemberantasan jentik, seperti mengurangi tempat gelap, tidak menggantung pakaian kotor dan menjaga kebersihan lingkungan rumah agar tidak lembab (Sarudji, 2010). Penyebaran DBD bisa dicegah dengan melakukan RBJ (Rumah Bebas Jentik) yang dilakukan secara berkala. Pemberantasan jentik dimulai dari lingkungan rumah, sehingga menjadi rumah yang terbebas dari jentik. Melakukan kegiatan rutin seperti bak kamar mandi yang dikuras dan disikat, TPA (Tempat Penampungan Air) yang ditutup dan barang-barang bekas yang dikubur serta menghindari gigitan nyamuk (Proverawati, 2012).

Hasil uraian di atas diketahui bahwa upaya preventif dalam pencegahan DBD yaitu tindakan pemberantasan sarang nyamuk dimulai dari jentik, larva, kepompong hingga dewasa. Cara lain untuk memberantas sarang nyamuk dengan $3 \mathrm{M}$ yaitu dengan memastikan lingkungan bebas dari genangan air, seperti cek tatakan kulkas, pot bunga, tempat minum burung. Pastikan untuk selalu bebas jentik, seperti menutup air tendon, lubang pohon, selokan maupun tempat sampah yang berpotensi menampung air saat hujan juga ban, kaleng, dan plastik bekas. Selain upaya preventif upaya promotif juga dapat dilakukan dalam pencegahan BDD.

Promosi Kesehatan adalah suatu proses yang memungkinkan orang untuk meningkatkan kendali (control) atas kesehatannya, dan meningkatkan status kesehatan mereka (Ottawa Charter, 1986; Notoadmodjo, 2010). Kementerian Kesehatan Republik Indonesia mengeluarkan buku Pedoman Pengendalian Demam Berdarah Dengue di Indonesia sebagai upaya promotif dan preventif dalam pengendalian DBD (Kemenkes, 2013), meliputi:

1. Pembudayaan pemberantasan sarang nyamuk (PSN) 3M Plus secara berkelanjutan sepanjang tahun dan mewujudkan terlaksananya Gerakan 1 Rumah 1 Jumantik

2. Membentuk Kelompok Kerja Operasional (Pokjanal) DBD di setiap tingkat administrasi dan melakukan revitalisasi Pokjanal DBD yang sudah ada dengan dukungan APBD

3. Upaya promosi kesehatan dilakukan di semua sektor, termasuk pembentukan Juru Pembasmi Jentik (Jumantik) pada anak sekolah dan pramuka

4. Penemuan dini kasus DBD dan pengobatan segera (early diagnosis and prompt treatment) yang merupakan bagian dari tata laksana kasus di fasilitas pelayanan kesehatan tingkat pertama dan lanjutan (Puskesmas dan Rumah Sakit)

5. Pelatihan tatalaksana kasus untuk Dokter dan Tenaga Kesehatan di Puskesmas dan Rumah Sakit

6. Penyediaan logistik tatalaksana kasus DBD berupa Rapid Diagnostik Tes (RDT) dan reagen untuk diagnosis serotype virus DBD

7. Pelaksanaan surveilans kasus DBD untuk memantau dinamika kejadian penyakit DBD di Indonesia sehingga kemungkinan terjadinya KLB DBD dapat diantisipasi dan dicegah sejak dini

8. Pelaksanaan surveilans vektor Aedes spp. untuk memantau dinamika vektor dengan demikian peningkatan populasi Aedes spp dapat diantisipasi.

Beberapa hal yang memengaruhi kejadian demam berdarah diteliti oleh Pramudiyo Teguh Sucipto dkk (2015), terdapat 5 variabel yang memengaruhi 
kejadian demam berdarah yaitu: kepadatan jentik, perilaku menggantung pakaian, kadar uap air di udara dalam ruangan, keberadaan jentik pada tempat penyimpanan air, dan penggunaan repellent.

Keberadaan jentik merupakan indikator adanya potensi terjadi demam berdarah, oleh sebab itu perilaku dalam pemberantasan jentik dijadikan sebagai solusi dalam upaya pencegahan demam berdarah. Perilaku Pemberantasan Sarang Nyamuk (PSN) akan mampu meningkatkan derajat kesehatan. Pemberantasan jentik diharapkan dapat dilakukan secara berkesinambungan, sehingga mampu memutus mata rantai vektor perkembangbiakan nyamuk. Keberlangsungan program diperlukan pelaku dalam menjalankan program tersebut agar berjalan secara berkelanjutan, sehingga dalam program Pemberantasan Sarang Nyamuk (PSN) diperlukan kerja sama yaitu dengan membentuk kader pemberantas jentik yang dikenal dengan Jumantik (Juru Pemantau Jentik). Keaktifan kader sangat berpengaruh terhadap keberhasilan pemberantasan sarang nyamuk. Banyak penelitian yang membahas tentang faktor yang memengaruhi keaktifan pemberantasan sarang nyamuk.

Sebuah studi yang dilakukan Puguh Ika Listyorini pada tahun 2016, diketahui beberapa faktor yang memengaruhi perilaku pemberantasan sarang nyamuk pada masyarakat Karangjati Kabupaten Blora antara lain pengetahuan, sikap, ketersediaan informasi, dan peran petugas. Faktor lain yang juga memengaruhi partisipasi Kader Jumantik dalam pemberantasan DBD di Desa Ketintang adalah pendidikan, penghasilan, jenis Pekerjaan, dan ketersediaan fasilitas (Pambudi, 2009).

Penelitian lain yang juga mendukung pernyataan tersebut dilakukan oleh Hafshah Riza Fawzia (2012) yang melakukan penelitian tentang Faktor Yang Memengaruhi Partisipasi Kader Jumantik dalam Upaya Pemberantasan Sarang Nyamuk di Desa Wirogunan didapat beberapa variabel yang berpengaruh yaitu pendidikan dan jenis pekerjaan. Banyak penelitian yang membahas tentang faktor yang memengaruhi pemberantasan sarang nyamuk, namun jarang yang menghubungkan dengan keberadaan jentik. Sebuah studi tentang keberadaan jentik pernah diteliti oleh Nani (2016), dalam penelitian yang dilakukan di Pelabuhan Pulang Pisau didapat bahwa pengetahuan PSN yang kurang, sikap PSN yang negative, dan tindakan PSN yang buruk ditemukan jentik Aedes aegypti di rumahnya.

Penjelasan diatas dapat diketahui bahwa keberadaan jentik berpengaruh dengan terjadinya demam berdarah, sehingga rumusan masalah dalam penelitian ini berfokus pada faktor yang memengaruhi keberadaan jentik di wilayah RW. VI Kelurahan Rangkah Buntu, Kota Surabaya. Tujuan penelitian ini adalah mengetahui faktor yang memengaruhi keberadaan jentik. Penelitian ini diharapkan bermanfaat bagi Puskesmas Rangkah, sehingga kasus DB tidak terulang.

\section{METODE}

Penelitian ini jenisnya adalah penelitian observasional analitik, desain yang digunakan adalah cross sectional. Peneliti hanya melakukan observasi dengan memperhatikan determinan yang berhubungan dengan keberadaan jentik, yaitu pendidikan, pendapatan, pengetahuan, sikap, tindakan $(3 \mathrm{M}+$, Menguras bak mandi minimal satu minggu sekali, menggantung pakaian kotor lebih dari satu hari), dan kebiasaan membersihkan rumah tanpa memberikan perlakuan yang dilakukan sekaligus pada suatu waktu (point time approach). Penelitian ini dilakukan pada bulan Januari hingga Februari 2018. Populasi penelitian ini didasarkan dari seluruh Kartu Keluarga (KK) RW.VI Kelurahan Rangkah Buntu yang diwakili satu orang per KK, sehingga populasi dalam penelitian ini berjumlah 447 orang kemudian diambil sampel dengan metode simple random sampling dengan perhitungan menggunakan rumus Slovin dan didapat 211 responden yang ditetapkan menjadi sampel.

Data kuantitatif dikumpulkan melalui indepth interview dan observasi dengan form observasi yang dijadikan instrumen untuk mengetahui keberadaan jentik dan kondisi kebersihan di lingkungan sekitar 
rumah. Pengumpulan data juga dilakukan dengan kuesioner yang berisi karakteristik responden, meliputi jenis kelamin, umur, pendidikan, pendapatan, serta perilaku responden yang mencakup pengetahuan, sikap, dan tindakan responden. Tiga kategori untuk pendidikan yaitu SD/SMP merupakan pendidikan rendah, SMA/SMK pendidikan menengah dan D3/S1 pendidikan tinggi. Tiga kategori juga digunakan untuk penghasilan yaitu penghasilan $>3.500 .000 /$ bulan merupakan golongan penghasilan sangat tinggi, Rp. 2.500.000-3.500.000/ bulan penghasilan tinggi, Rp. 1.500.0002.500.000/bulan penghasilan sedang dan $\leq$ Rp. 1.500.000/bulan penghasilan rendah.

Lima pertanyaan diukur dengan menggunakan pernyataan benar atau salah untuk mengetahui tingkat pengetahuan responden. Kemudian hasil pengetahuan dibagi menjadi tiga kategori, untuk pertanyaan yang dijawab benar $>75 \%$ (>4 pertanyaan) maka dikatakan bahwa responden memiliki pengetahuan yang baik, 60-75\% (3 pertanyaan) pengetahuan cukup dan $<60 \%$ ( $\leq 2$ pertanyaan) pengetahuan kurang. Skala likert digunakan untuk mengukur sikap. Dua kategori untuk menilai sikap yaitu jika skor menunjukkan > median maka dikatakan responden memiliki sikap yang baik dan skor $\leq$ median menunjukkan sikap kurang. Median merupakan nilai hasil penjumlahan antara skor minimal dan skor maksimal lalu dibagi dalam kategori yang diinginkan. Skor >14, maka dapat dikatakan responden memiliki sikap yang baik dan skor $\leq 14$ artinya responden memiliki sikap kurang.

Pengolahan data dilakukan dengan cara editing, coding, dan entry data. Teknik analisa data digunakan untuk menganalisis tiap variabel. Tabulasi didapat dari analisis data menggunakan statistik deskriptif, sedangkan untuk melihat hubungan antar variabel digunakan uji chi-square kemudian bentuk distribusi frekuensi atau presentase (\%) dari tiap tabel dilaporkan sebagai hasil analisis.

\section{HASIL DAN PEMBAHASAN}

Hasil penelitian yang dilakukan di wilayah RW. VI Kelurahan Rangkah Buntu, Kota Surabaya melalui observasi keberadaan jentik, dari 211 rumah yang didatangi diketahui bahwa responden yang terdapat keberadaan jentik di rumahnya sebesar 121 rumah $(57 \%)$ dan rumah responden yang tidak terdapat jentik sebesar 90 rumah (43\%).

Tabel 1 menyajikan hasil penelitian. Sebagian besar responden diketahui berjenis kelamin perempuan sebesar $88 \%$, dengan usia terbanyak 41-65 tahun yaitu $48 \%$, berpendidikan rendah sebanyak $50 \%$ dan pendapatan responden hampir tersebar merata yaitu masing-masing sekitar $34 \%$.

Pada tabel 2, dari hasil penelitian dapat dilihat hubungan variabel independen dengan keberadaan jentik yang disajikan dalam bentuk frekuensi. Tabel 2 menunjukkan bahwa sebagian besar responden yang berpendidikan rendah terdapat jentik dalam rumahnya yaitu sebesar $57,7 \%$. Jumlah pendapatan dapat diinterpretasikan bahwa persebaran jentik cukup merata antara responden dengan pendapatan rendah hingga tinggi, namun bagi responden yang berpendapatan sedang keberadaan jentik lebih dari setengahnya, yaitu $62,5 \%$. Separuh responden memiliki pengetahuan yang baik. Responden yang memiliki pengetahuan baik, ternyata juga ditemukan jentik didalam rumahnya, yaitu sebesar 68,9\%. Hampir seluruh responden memiliki sikap yang baik. Sebagian besar

Tabel 1. Distribusi Frekuensi Karakteristik Responden di Kelurahan Rangkah Buntu Tahun 2018

\begin{tabular}{lrr}
\hline \multirow{2}{*}{ Karakteristik } & \multicolumn{2}{c}{ Responden } \\
\cline { 2 - 3 } & F & $\%$ \\
\hline Jenis Kelamin & & \\
Laki-laki & 26 & 12 \\
Perempuan & 185 & 88 \\
\hline Umur & & \\
12-17 tahun & 1 & 1 \\
18-40 tahun & 83 & 39 \\
41-65 tahun & 101 & 48 \\
$>66$ tahun & 26 & 12 \\
\hline Pendidikan & & \\
Tinggi & 7 & 3 \\
Menengah & 100 & 47 \\
Rendah & 104 & 50 \\
\hline Pendapatan & & \\
Sangat tinggi & 0 & 0 \\
Tinggi & 71 & 34 \\
Sedang & 72 & 34 \\
Rendah & 68 & 32 \\
\hline
\end{tabular}


Tabel 2. Distribusi Frekuensi Responden berdasarkan Variabel Independen terhadap Keberadaan Jentik di Kelurahan Rangkah Buntu Tahun 2018

\begin{tabular}{|c|c|c|c|}
\hline \multirow{3}{*}{$\begin{array}{l}\text { Variabel } \\
\text { Independen }\end{array}$} & \multicolumn{2}{|c|}{$\begin{array}{c}\text { Keberadaan } \\
\text { Jentik }\end{array}$} & \multirow{2}{*}{ Total } \\
\hline & $\begin{array}{c}\text { Ada } \\
\text { Jentik }\end{array}$ & $\begin{array}{l}\text { Bebas } \\
\text { Jentik }\end{array}$ & \\
\hline & $F$ & $F$ & $F$ \\
\hline \multicolumn{4}{|l|}{ Pendidikan } \\
\hline Tinggi & 4 & 3 & 7 \\
\hline Sedang & 57 & 43 & 100 \\
\hline Rendah & 60 & 44 & 104 \\
\hline \multicolumn{4}{|l|}{ Pendapatan } \\
\hline Sangat tinggi & 0 & 0 & 0 \\
\hline Tinggi & 40 & 31 & 71 \\
\hline Sedang & 45 & 27 & 72 \\
\hline Rendah & 36 & 32 & 68 \\
\hline \multicolumn{4}{|l|}{ Pengetahuan } \\
\hline Baik & 73 & 33 & 106 \\
\hline Cukup & 9 & 17 & 26 \\
\hline Kurang & 39 & 40 & 79 \\
\hline \multicolumn{4}{|l|}{ Sikap } \\
\hline Baik & 121 & 88 & 209 \\
\hline Kurang & 0 & 2 & 2 \\
\hline \multicolumn{4}{|l|}{$3 M+$} \\
\hline $\mathrm{Ya}$ & 92 & 66 & 159 \\
\hline Tidak & 29 & 23 & 52 \\
\hline \multicolumn{4}{|c|}{$\begin{array}{l}\text { Menguras bak mandi minimal satu kali } \\
\text { seminggu }\end{array}$} \\
\hline $\mathrm{Ya}$ & 58 & 57 & 115 \\
\hline Tidak & 63 & 33 & 96 \\
\hline \multicolumn{4}{|c|}{$\begin{array}{l}\text { Menggantung pakaian kotor lebih dari } \\
\text { satu hari }\end{array}$} \\
\hline $\mathrm{Ya}$ & 51 & 54 & 105 \\
\hline Tidak & 70 & 36 & 106 \\
\hline \multicolumn{4}{|c|}{ Membersihkan rumah } \\
\hline Setiap hari & 108 & 76 & 184 \\
\hline Kadang & 13 & 14 & 27 \\
\hline
\end{tabular}

responden melakukan $3 M_{+}$, dari seluruh responden yang melakukan $3 \mathrm{M}+$ lebih dari separuh terdapat jentik di rumahnya, yaitu sebesar $57,9 \%$.

Diketahui tidak ada hubungan signifikan sikap dengan keberadaan jentik. Artinya sikap responden tidak berpengaruh terhadap keberadaan jentik di Kelurahan Rangkah, Surabaya. Tidak ada hubungan yang signifikan antara $3 M+$ dengan keberadaan jentik. Artinya $3 M+$ yang dilakukan responden tidak berpengaruh terhadap keberadaan jentik di Kelurahan Rangkah, Surabaya.

Ada hubungan yang signifikan antara menguras bak mandi minimal sekali seminggu dengan keberadaan jentik. Artinya kebiasaan menguras bak mandi minimal sekali seminggu responden berpengaruh terhadap keberadaan jentik di Kelurahan Rangkah.

Ada hubungan yang signifikan antara menggantung pakaian kotor lebih dari satu hari dengan keberadaan jentik. Artinya kebiasaan menggantung pakaian kotor lebih dari satu hari oleh responden berpengaruh terhadap keberadaan jentik di Kelurahan Rangkah, Surabaya.

Tidak ada hubungan yang signifikan antara membersihkan rumah dengan keberadaan jentik. Artinya responden dengan kebiasaan membersihkan rumah tidak berpengaruh terhadap keberadaan jentik di Kelurahan Rangkah, Surabaya. Berikut adalah rangkuman dari hasil analisis bivariat melalui uji Chi Square yang disajikan dalam Tabel 4.

Wilayah RW. VI Kelurahan Rangkah Buntu, Kota Surabaya dipilih karena terdapat empat kasus demam berdarah di akhir tahun 2017, setelah dilakukan pemeriksaan banyak ditemukan keberadaan jentik di rumah warga. Jentik merupakan indikator terjadinya demam berdarah, sehingga populasinya harus diberantas atau dikurangi. Demi tercapainya tujuan tersebut pemerintah mencanangkan program Jumantik (Juru Pemantau Jentik) sebagai upaya Pemberantasan Sarang Nyamuk (PSN). Hal ini tertulis dalam pedoman Kemenkes (2013) yang menyatakan bahwa upaya Pemberantasan Sarang Nyamuk bisa dilakukan dengan membentuk Juru Pemantau Jentik (Jumantik), Satu Rumah Satu Jumantik.

Bumantik (Ibu pemantau jentik) di Kelurahan Rangkah Buntu sudah terbentuk. Kader ini baru saja mengalami regenerasi, banyak anggota baru yang direkrut mengganti bumantik yang lama. Bumantik di Kelurahan Rangkah Buntu terdiri dari 14 orang dan rutin melakukan pemeriksaan di rumah warga setiap hari minggu untuk memantau kegiatan pemberantasan sarang nyamuk yang dilakukan oleh warga. Pemeriksaan PSN dibagi per RT secara bergantian, kemudian menyebar 
Tabel 3. Hubungan Variabel Independen dengan Keberadaan Jentik di Kelurahan Rangkah Buntu Tahun 2018

\begin{tabular}{|c|c|c|c|}
\hline \multirow[b]{2}{*}{ Variabel Independen } & \multicolumn{2}{|c|}{ Keberadaan Jentik } & \multirow[b]{2}{*}{ P-value } \\
\hline & $\begin{array}{l}\text { Ada Jentik } \\
\text { (\%) }\end{array}$ & $\begin{array}{c}\text { Bebas Jentik } \\
(\%)\end{array}$ & \\
\hline \multicolumn{4}{|l|}{ Pendidikan } \\
\hline Tinggi & 57,1 & 42,9 & \multirow{3}{*}{0,995} \\
\hline Sedang & 57 & 43 & \\
\hline Rendah & 57,7 & 42,3 & \\
\hline \multicolumn{4}{|l|}{ Pendapatan } \\
\hline Sangat tinggi & 0 & 0 & \multirow{4}{*}{0,509} \\
\hline Tinggi & 56,3 & 43,7 & \\
\hline Sedang & 62,5 & 37,5 & \\
\hline Rendah & 52,9 & 47,1 & \\
\hline \multicolumn{4}{|l|}{ Pengetahuan } \\
\hline Baik & 68,9 & 31,1 & \multirow{3}{*}{0,001} \\
\hline Cukup & 34,6 & 65,4 & \\
\hline Kurang & 49,4 & 50,6 & \\
\hline \multicolumn{4}{|l|}{ Sikap } \\
\hline Baik & 57,9 & 42,1 & \multirow{2}{*}{0,353} \\
\hline Kurang & 0 & 100 & \\
\hline \multicolumn{4}{|l|}{$3 M+$} \\
\hline Ya & 57,9 & 42,1 & \multirow{2}{*}{0,918} \\
\hline Tidak & 55,8 & 44,2 & \\
\hline \multicolumn{4}{|c|}{ Menguras bak mandi minimal sekali seminggu } \\
\hline Ya & 50,4 & 49,6 & \multirow[t]{2}{*}{0,037} \\
\hline Tidak & 65,6 & 34,4 & \\
\hline \multicolumn{4}{|c|}{ Menggantung pakaian kotor lebih dari satu hari } \\
\hline Ya & 48,6 & 51,4 & \multirow[t]{2}{*}{0,015} \\
\hline Tidak & 66 & 34 & \\
\hline \multicolumn{4}{|l|}{ Membersihkan rumah } \\
\hline Setiap hari & 58,7 & 41,3 & \multirow[t]{2}{*}{0,409} \\
\hline Kadang-kadang & 48,1 & 51,9 & \\
\hline
\end{tabular}

Tabel 4. Rangkuman hasil analisis bivariat melalui uji Chi Square

\begin{tabular}{lccc}
\hline \multicolumn{1}{c}{ Variabel } & Nilai $\mathbf{p}$ & $\mathbf{a}$ & Keterangan \\
\hline Pendidikan & 0,995 & 0,05 & $\begin{array}{c}\text { Tidak ada hubungan yang } \\
\text { signifikan }\end{array}$ \\
\hline Pendapatan & 0,509 & 0,05 & $\begin{array}{c}\text { Tidak ada hubungan yang } \\
\text { signifikan }\end{array}$ \\
\hline Pengetahuan & 0,001 & 0,05 & Ada hubungan yang signifikan \\
\hline Sikap & 0,353 & 0,05 & $\begin{array}{c}\text { Tidak ada hubungan yang } \\
\text { signifikan }\end{array}$ \\
\hline $3 \mathrm{M}+$ & 0,918 & 0,05 & $\begin{array}{c}\text { Tidak ada hubungan yang } \\
\text { signifikan }\end{array}$ \\
\hline $\begin{array}{l}\text { Menggantung pakaian kotor lebih dari } \\
\text { satu hari }\end{array}$ & 0,015 & 0,05 & Ada hubungan yang signifikan \\
\hline $\begin{array}{l}\text { Menguras bak mandi minimal satu kali } \\
\text { seminggu }\end{array}$ & 0,037 & 0,05 & Ada hubungan yang signifikan \\
\hline \begin{tabular}{l} 
Membersihkan rumah \\
\hline
\end{tabular} & 0,409 & 0,05 & $\begin{array}{c}\text { Tidak ada hubungan yang } \\
\text { signifikan }\end{array}$ \\
\hline
\end{tabular}

\section{Jurnal Promkes}


di lingkungan RT tersebut. Setiap dua orang bumantik mendapat jatah untuk memeriksa 20 rumah, kemudian dilakukan pencatatan untuk selanjutnya direkap dan dilaporkan kepada Puskesmas Rangkah. Keaktifan bumantik sangat penting dalam penyelenggaraan Pemberantasan Sarang Nyamuk agar rantai perkembangan vektor Aedes dapat diputus dan terbebas dari jentik, sehingga dapat mengurangi kejadian demam berdarah. Beberapa determinan yang memengaruhi keberadaan jentik dijadikan sebagai variabel dalam penelitian ini.

\section{Pendidikan}

Pendidikan merupakan sebuah usaha nyata dan terencana untuk mengembangkan potensi diri, pengendalian diri, kepribadian kecerdasan, akhlak mulia serta keterampilan yang bermanfaat (UU No.20 Tahun 2003). Memperoleh dan mencerna informasi akan lebih mudah didapat oleh tingkat pendidikan yang tinggi, sehingga menerapkan hidup sehat akan lebih mudah untuk dipilih dalam kesehariannya. Pendidikan berhubungan dengan kemampuan menerima informasi kesehatan (Widoyono, 2008). Penelitian ini mendapatkan hasil tidak ada hubungan antara pendidikan dan keberadaan jentik.

Hal ini tidak sesuai dengan penelitian yang pernah dilakukan oleh Pambudi (2009) dalam skripsinya diketahui bahwa variabel yang berpengaruh terhadap partisipasi kader dalam pemberantasan DBD yaitu pendidikan, penghasilan, jenis Pekerjaan, dan ketersediaan fasilitas.

\section{Pendapatan}

Badan Pusat Statistik (2008) menggolongkan pendapatan menjadi beberapa tingkatan, yaitu pendapatan sangat tinggi dimana penghasilan lebih dari Rp 3.500.000 setiap bulan, pendapatan tinggi dimana penghasilan Rp 2.500.000 - Rp 3.500.000 setiap bulan, pendapatan sedang dimana penghasilan Rp 1.500.000 Rp 2.500.000 setiap bulan dan pendapatan rendah dimana penghasilan kurang dari Rp 1.500 .000 setiap bulan.

Semua penghasilan baik berupa uang ataupun jasa yang didapat oleh keluarga adalah bentuk dari pendapatan rumah tangga. Kecepatan seseorang untuk meminta pertolongan apabila anggota keluarganya sakit dapat dipengaruhi oleh kemampuan anggaran rumah tangga (Widoyono, 2008). Hasil dari penelitian ini tidak terdapat hubungan antara pendapatan dengan keberadaan jentik.

Pambudi (2009) dalam skripsinya didapatkan hasil bahwa penghasilan berpengaruh terhadap partisipasi kader dalam pemberantasan demam berdarah yang salah satunya dilakukan dengan Pemberantasan Sarang Nyamuk dalam upaya pengurangan jentik.

\section{Pengetahuan}

Hasil penginderaan manusia atau hasil tahu seseorang terhadap suatu objek dari indra yang dimilikinya adalah Pengetahuan (Notoatmodjo, 2012). Peningkatan pengetahuan diharapkan mampu meningkatkan kesadaran seseorang agar memiliki perilaku yang benar dalam memelihara kesehatan. Untuk itu perlu ditingkatkan kesadaran untuk masing-masing kader dengan mengadakan pelatihan ataupun pendampingan dalam pelaksanaan Pemberantasan Sarang Nyamuk. Pengetahuan yang baik akan dapat memengaruhi tindakan seseorang dalam pemberantasan sarang nyamuk sehingga kasus demam berdarah tidak kembali terulang (Helly Conry Pangemanan, 2016). Hasil penelitian ini diketahui bahwa pengetahuan berhubungan dengan keberadaan jentik.

Hal ini sesuai dengan penelitian Erni Nuryanti (2013) yang menyatakan bahwa perilaku pemberantasan sarang nyamuk berhubungan dengan pengetahuan, sikap, ketersediaan informasi serta peran petugas kesehatan. Penelitian lain yang juga meneliti tentang faktor yang memengaruhi partisipasi kader menyatakan bahwa variabel yang memengaruhi partisipasi kader Jumantik dalam upaya pemberantasan sarang nyamuk adalah pendidikan dan jenis pekerjaan (Hafshah Riza Fawzia, 2012).

Hal serupa juga pernah diteliti oleh Listyorini dan Puguh Ika (2016) tentang faktor-faktor yang memengaruhi perilaku Pemberantasan Sarang Nyamuk (PSN) pada masyarakat Karangjati, Blora didapat beberapa variabel yang memengaruhi perilaku PSN yaitu pengetahuan, sikap, 
ketersediaan informasi, dan peran petugas.

\section{Sikap}

Reaksi dari seseorang terhadap stimulus yang tertutup tidak dalam bentuk tindakan nyata, namun masih berupa kesiapan serta persepsi seseorang untuk bereaksi terhadap stimulus di sekitarnya merupakan definisi sikap. Pengukuran sikap bisa secara langsung maupun tidak langsung. Ungkapan oleh responden terhadap objek dijadikan pedoman dalam pengukuran sikap (Notoatmodjo, 2012). Hasil penelitian ini diketahui bahwa sikap tidak berhubungan dengan keberadaan jentik.

Hal ini tidak sesuai dengan penelitian yang pernah dilakukan oleh Yanuarita Tursinawati dan Afiana Rohmani (2016) yang menyatakan bahwa sikap berpengaruh terhadap pelaksanaan pemberantasan sarang nyamuk, yang juga berpengaruh terhadap keberadaan jentik.

\section{$3 \mathrm{M}$ plus}

Kegiatan pemberantasan sarang nyamuk (PSN) dilakukan secara periodic oleh masyarakat yang dikoordinir oleh RT/ RW dalam bentuk PSN dengan pesan inti $3 \mathrm{M}$ plus merupakan pengendalian vektor melalui surveilans vektor yang diatur dalam Kepmenkes No. 581 tahun 1992. $3 \mathrm{M}$ plus merupakan tindakan dalam upaya pencegahan penyakit demam berdarah yaitu dengan cara menguras, menutup, mengubur, dan menghindari gigitan nyamuk. Semua itu merupakan cara yang harus dilakukan agar rumah menjadi bebas jentik (Proverawati, 2012). Penelitian yang telah dilakukan di wilayah RW. VI Kelurahan Rangkah, Surabaya didapat hasil bahwa tidak ada hubungan antara $3 \mathrm{M}$ plus dengan keberadaan jentik.

Penelitian tentang perilaku pemberantasan sarang nyamuk dengan keberadaan jentik di Pelabuhan Pulang Pisau diketahui bahwa terdapat hubungan antara pengetahuan, sikap, dan tindakan dalam pemberantasan sarang nyamuk dengan kejadian demam berdarah (Nani, 2017). Salah satu tidak berhasilnya 3M plus di Kelurahan Rangkah Buntu ini disebabkan oleh sumber air. Pernyataan seorang warga yang didapat saat observasi, beberapa warga menyatakan bahwa tandon air yang baru saja dikuras sudah terdapat jentik didalamnya, kemudian dilakukan penelusuran dan ternyata terdapat banyak jentik di sumur warga.

\section{Menggantung Pakaian Kotor Lebih dari Satu Hari}

Nyamuk sangat menyukai genangan air, selain itu ia juga suka dengan tempat yang beraroma tubuh manusia contohnya pakaian yang baru dipakai dan meninggalkan bau keringat. Seseorang ingin menyimpan pakaian yang baru dipakai, sebaiknya simpan di tempat yang tertutup, atau segera masukkan ke mesin cuci (dr. Leonard Nainggolan dalam beritasatu.com, 2014). Hasil dari penelitian didapat hubungan antara menggantung pakaian kotor lebih dari satu hari dengan keberadaan jentik.

$\mathrm{Hal}$ ini serupa dengan pernyataan yang diutarakan oleh Abd. Majid HR. Lagu dkk (2017), dalam penelitiannya yang menjadikan kebiasaan menggantung pakaian sebagai salah satu variabel $3 \mathrm{M}$ plus, didapat hasil bahwa menggantung pakaian dalam rumah berhubungan dengan keberadaan jentik.

\section{Menguras Bak Mandi Minimal Satu Kali Seminggu}

Waktu kira-kira 2 hari, umumnya telur akan menetas menjadi larva setelah telur terendam air. Nyamuk betina meletakkan telur di dinding wadah di atas permukaan air dalam keadaan menempel pada dinding perindukannya.

Sebanyak 100 butir dikeluarkan setiap kali betina bertelur, kemudian selama 8-12 hari (fase aquatic), stadium jentik berlangsung di hari 6-8, dan stadium pupa sekitar 2-4 hari. Dibutuhkan 10-14 hari bagi nyamuk untuk melakukan pertumbuhan dimulai dari telur sampai menjadi nyamuk dewasa. Umur nyamuk dapat mencapai 2-3 bulan. Ae. aegypti mengalami metamorfosis lengkap atau metamorfosis sempurna (holometabola) yang melalui beberapa (Hoedoyo, dkk, 2013), sehingga menguras bak mandi minimal seminggu sekali diharapkan dapat memutus siklus vektor Aedes. Hal ini sesuai dengan hasil yang didapat dari penelitian ini, yaitu terdapat hubungan yang signifikan antara menguras bak mandi minimal seminggu sekali dengan keberadaan jentik. 


\section{Membersihkan Rumah}

Upaya dalam menciptakan lingkungan rumah yang bersih dan sehat adalah dengan membersihkannya. Siang hari adalah waktu aktif nyamuk Aedes sp. dan biasanya akan berbiak dan meletakkan telurnya pada genangan air atau tempat penampungan hujan. Sebuah tempat penampungan air, tempat untuk bunga seperti pot atau vas bunga, botol atau tabung dengan rongga yang sudah tidak terpakai yang memungkinkan air menggenang, tempat aliran air talang rumah, wadah yang terbuat dari plastik atau kantung bekas, di atas lantai gedung terbuka, bambu yang dijadikan sebagai pagar, sisa kulit buah (rambutan, tempurung kelapa), lengkungan pada bentuk kontainer yang dapat menampung air bersih merupakan contoh tempat genangan air (Sembel DT, 2009).

Bangunan rumah bagian dalam lebih dusukai Aedes aegypti dewasa untuk hidup dan mencari mangsa sedangkan lingkungan luar seperti kebun atau tanaman yang rimbun lebih disukai Aedes albopictus. (Soedarto, 2008). Antara 50 sampai 100 mil merupakan jarak terbang maksimum breding place dengan sumber makanan pada Aedes sp. Keberadaan manusia atau hewan, cahaya terang ataupun warna pakaian yang mencolok sering menjadi perhatian nyamuk. Kegiatan membersihkan rumah setiap hari dapat dijadikan alternatif untuk memutus perkembangbiakan vektor Aedes. Penelitian ini menunjukkan tidak ada hubungan antara membersihkan rumah setiap hari dengan keberadaan jentik. Hal ini bisa dikaitkan dengan sumber air yang digunakan warga, yaitu air sumur yang masih ditemukan jentik. Lingkungan juga berpengaruh dengan keberadaan jentik tersebut seperti keberadaan tempat sampah yang terbuka dan ada beberapa got yang tidak tertutup di wilayah RW.VI Kelurahan Rangkah, Surabaya. Hal ini berpotensi menimbulkan genangan dan bisa dijadikan tempat perindukan nyamuk.

\section{SIMPULAN}

Tidak ada hubungan yang signifikan antara pendidikan, pendapatan, sikap, $3 \mathrm{M}+$, dan membersihkan rumah dengan keberadaan jentik di wilayah RW.VI Kelurahan Rangkah Buntu, Kota Surabaya. Hubungan yang signifikan didapat antara pengetahuan, menggantung pakaian kotor lebih dari satu hari dan menguras bak mandi minimal sekali seminggu dengan keberadaan jentik di wilayah RW. VI Kelurahan Rangkah Buntu, Kota Surabaya.

\section{DAFTAR PUSTAKA}

Badan Pusat Statistik. 2008. "Penggolongan Pendapatan Penduduk". Jakarta: BPS.

Blum, H,L. 1974. "Planning for Health: Development Application of Social Change Theory". New York.

Fawzia, Hafshah Riza. 2012. "Faktor-Faktor yang Memengaruhi Partisipasi Kader Jumantik dalam Upaya Pemberantaan Sarang Nyamuk di Desa Wirogunan Kecamatan Kartasura Kabupaten Sukoharjo" [Skripsi]. Surakarta: Program Studi Kesehatan Masyarakat Fakultas Ilmu Kesehatan Universitas Muhammadiyah Surakarta

Hendri, Joni, dkk. “Tempat Perkembangbiakan Nyamuk Aedes spp. di Pasar Wisata Pangandaran", Jurnal Aspirator Vol. 2 No. 1 Tahun 2010 : 23-31.

Herman. 2014. "Gantung Pakaian Kotor Bisa Undang Nyamuk Aedes Aegypti". [beritasatu.com].

Hoedojo R, S. Sungkar. 2013. "Parasitologi Kedokteran Edisi Keempat”. Jakarta: Badan Penerbit Fakultas Kedokteran Universitas Indonesia.

Grahadi. 2017. "Jumlah Kasus Demam Berdarah di Jatim Menurun berkat Tiga Program ini". [surabaya.tribunnews. com].

Ishartadiati. K. 2012. “Aedes aegypti sebagai Vektor Demam Berdarah Dengue” [Naskah Publikasi]. Surabaya: Universitas Wijaya Kusuma Surabaya

Kemenkes RI. 2013. "Pedoman Pengendalian Demam Berdarah Dengue di Indonesia”. Jakarta : Ditjen PP dan PL.

Kemenkes. 2016. "Pusat Informasi dan Data Situasi DBD di Indonesia”. Jakarta: Kementerian Kesehatan RI.

Kurniawan, Hendra. 2011. "Peran Faktor Lingkungan Terhadap Penyakit dan Penularan Demam Berdarah Dengue", Jurnal Kedokteran Syiah Kuala Volume 11 Nomor 1 April 2011. 
Lagu, Abd. Majid HR, dkk, “Hubungan Jumlah Penghuni, Jumlah Tempat Penampungan Air dan Pelaksanaan 3M Plus dengan Keberadaan Jentk Nyamuk Aedes Sp di Kelurahan Balleangin Kecamatan Balocci Kabupaten Pangkep" Jurnal Higiene Volume 3, No. 1, Januari-April 2017.

Listyorini, Puguh Ika, "Faktor-Faktor yang Memengaruhi Perilaku Pemberantasan Sarang Nyamuk (PSN) pada Masyarakat Karangjati Kabupaten Blora", Jurnal Ilmiah Rekam Medis dan Informatika Kesehatan Infokes, Vol 6 No 1, Juli 2016 ISSN : 2086 - 2628.

Notoadmodjo, S. 2010. "Promkes teori dan aplikasi”. Jakarta: Rineka Cipta.

Notoadmodjo, S. 2012. "Ilmu perilaku kesehatan". Jakarta: Rineka Cipta.

Nuryanti, Erni, "Perilaku Pemberantasan Sarang Nyamuk di Masyarakat", Jurnal Kesmas 9 (1), 2013, hlm. 15-23.

Pambudi. 2009. "Faktor-Faktor yang Memengaruhi Partisipasi Kader Jumantik dalam Pemberantasan DBD di Desa Ketitang Kecamatan Nogosari Kabupaten Boyolali Tahun 2009" [Skripsi]. Surakarta: Program Studi Kesehatan Masyarakat Fakultas IImu Kesehatan Universitas Muhammadiyah Surakarta.

Pramudiyo, Mursid, \& Nurjazuli. “Faktor - Faktor yang Memengaruhi Kejadian Penyakit Demam Berdarah Dengue (DBD) dan Jenis Serotipe Virus Dengue di Kabupaten Semarang", Jurnal Kesehatan Lingkungan Indonesia Vol. 14 No. 2 Tahun 2015.
Proverawati. 2012. "Perilaku Hidup Bersih dan Sehat (PHBS)". Yogyakarta: Nuha Medika.

Pusat Data. “Deman BD”. Buletin Jendela Epidemiologi, Volume 2, Agustus 2010.

Sarudji. 2010. "Kesehatan Lingkungan, Cetakan Pertama”. Bandung: Karya Putra Darwati.

Sembel DT. 2009. "Entomologi Kedokteran". Yogyakarta: Andi Publisher.

Sherrie V. Bain, “Dengue Fever: An Emerging Infectious Disease in The Bahamas", The International Journal of Bahamian Studies, Vol.17, no.2 2011.

Soedarto. 2008. "Parasitologi Klinik". Surabaya: Airlangga University Press.

Tursinawati, dkk. 2016. "Pelaksanaan pemberantasan sarang nyamuk DBD berbasir perilaku masyarakat di Kalipancur Semarang" [Rakernas AIPKEMA] "Temu Ilmiah Hasil Penelitian dan Pengabdian Masyarakat".

Undang-Undang Republik Indonesia Nomor 20 Tahun 2003 tentang Sistem Pendidikan Nasional [kelembagaan.ristekdikti. go.id].

Widoyono. 2008. "Penyakit Tropis: Epidemiologi, Penularan, Pencegahan, dan Pemberantasannya". Semarang: Erlangga.

World Health Organization. 2009. "Dengue and dengue haemorrhagic fever" [who. int].

Yimer Muktar, Nateneal Tamerat and Abnet Shewafera, "Aedes aegypti as a Vektor of Flavivirus", Journal of Tropical Diseases \& Public Health, Volume 4, Issue 5, October 31, 2017. 